\title{
Impact of Poultry Litter Cake, Cleanout, and Bedding following Chemical Amendments on Soil C and N Mineralization
}

\author{
Dexter B. Watts, ${ }^{1}$ Katy E. Smith, ${ }^{2}$ and H. A. Torbert ${ }^{1}$ \\ ${ }^{1}$ National Soil Dynamics Laboratory, USDA-ARS, 411 S. Donahue Drive, Auburn, AL 36832, USA \\ ${ }^{2}$ Depatement of Math, Science, and Technology, University of Minnesota-Crookston, 2900 University Avenue, Crookston, \\ MN 56716, USA
}

Correspondence should be addressed to Dexter B. Watts, dexter.watts@ars.usda.gov

Received 7 January 2012; Accepted 2 April 2012

Academic Editor: Mark Reiter

Copyright ( 2012 Dexter B. Watts et al. This is an open access article distributed under the Creative Commons Attribution License, which permits unrestricted use, distribution, and reproduction in any medium, provided the original work is properly cited.

Poultry litter is a great alternative $\mathrm{N}$ source for crop production. However, recent poultry litter management changes, and increased chemical amendment use may impact its $\mathrm{N}$ availability. Thus, research was initiated to evaluate the effect that broiler cake and total cleanout litter amended with chemical additives have on $\mathrm{C}$ and $\mathrm{N}$ mineralization. A 35-day incubation study was carried out on a Hartsells fine sandy loam (fine-loamy, siliceous, subactive, thermic Typic Hapludults) soil common to the USA Appalachian Plateau region. Three poultry litter components (broiler cake, total cleanout, and bedding material) from a broiler house were evaluated and compared to a soil control. Chemical amendments lime $\left(\mathrm{CaCO}_{3}\right)$, gypsum $\left(\mathrm{CaSO}_{4}\right)$, aluminum sulfate $\left.(\mathrm{AlSO})_{4}\right)$, and ferrous sulfate $\left(\mathrm{FeSO}_{4}\right)$ were added to the poultry litter components to determine their impact on $\mathrm{C}$ and $\mathrm{N}$ mineralization. Litter component additions increased soil C mineralization in the order of broiler cake $>$ total cleanout $>$ bedding $>$ soil control. Although a greater concentration of organic $\mathrm{C}$ was observed in the bedding, broiler cake mineralized the most $\mathrm{C}$, which can be attributed to differences in the $\mathrm{C}: \mathrm{N}$ ratio between treatments. Chemical amendment in addition to the manured soil also impacted $\mathrm{C}$ mineralization, with $\mathrm{AlSO}_{4}$ generally decreasing mineralization. Nitrogen mineralization was also significantly affected by poultry litter component applications. Broiler cake addition increased $\mathrm{N}$ availability followed by total cleanout compared to soil control, while the bedding resulted in net $\mathrm{N}$ immobilization. Chemical amendments impacted $\mathrm{N}$ mineralization primarily in the broiler cake amended soil where all chemical amendments decreased mineralization compared to the no chemical amendment treatment. This short-term study (35-day incubation) indicates that $\mathrm{N}$ availability to crops may be different depending on the poultry litter component used for fertilization and chemical amendment use which could decrease $\mathrm{N}$ mineralization.

\section{Introduction}

Poultry litter is increasingly being demanded as an alternative nutrient source to commercial fertilizer in the southeastern US region. Poultry litter is regarded as one of the most valuable nutrient sources compared to other manures due to its relatively high $\mathrm{N}$ and phosphorus (P) content. However, poultry litter's $\mathrm{N}$ and $\mathrm{P}$ may be susceptible to environmental loss. This has resulted in the increased use of chemical amendments to specifically reduce surface water P loss and $\mathrm{NH}_{3}$ volatilization. Concurrently, poultry litter management practices have also recently changed, with most poultry producers cleaning the litter out of their houses less often to reduce labor costs. The impact that increased chemical amendment use and the changes in poultry litter management practices will have on $\mathrm{N}$ availability to plants is largely unknown.

Previous studies have shown that the abatement of $\mathrm{P}$ transport from land applied manure to water bodies can be achieved with the use of chemical amendments containing aluminum $(\mathrm{Al})$, iron $(\mathrm{Fe})$, or calcium $(\mathrm{Ca})[1-$ 7]. These compounds ( $\mathrm{Al}, \mathrm{Fe}$, or, $\mathrm{Ca}$ ) work by binding to $\mathrm{P}$ in solution thereby forming insoluble compounds. For instance, Ca rich compounds (gypsum and lime) used as soil amendments tend to form insoluble $\mathrm{P}$ compounds, largely as a result of forming a Ca phosphate complex [8]. Aluminum and ferrous compounds (aluminum sulfate and ferrous sulfate) usually result in decreased $\mathrm{pH}$. Consequently as $\mathrm{pH}$ 
decreases, $\mathrm{Al}$ and $\mathrm{Fe}$ salts result in the precipitation of aluminum hydroxy phosphate and ferrous hydroxy phosphate [9].

Similarly, $\mathrm{Al}, \mathrm{Fe}$, and $\mathrm{Ca}$ compounds are believed to reduce ammonia volatilization from poultry litter. Ammonia volatilization occurs through enzymatic conversion and decomposition of organic nitrogenous compounds contained in poultry litter. Reece et al. [10] reported that $\mathrm{NH}_{3}$ volatilization can be reduced when the litter $\mathrm{pH}$ falls below 7, while it is greatly increased when $\mathrm{pH}$ is above 8 . Thus, chemical additives that manipulate poultry litter's $\mathrm{pH}$ are believed to be the most effective. Kithome et al. [11] evaluated effects of the chemical amendments gypsum $\left(\mathrm{CaSO}_{4}\right)$ and aluminum sulfate $\left(\mathrm{Al}_{2} \mathrm{SO}_{4}\right)$ as reducing agents, influencing ammonia volatilization. A mixture of $20 \% \mathrm{Al}_{2} \mathrm{SO}_{4}$ effectively reduced ammonia emissions by $74 \%$ compared to control, while gypsum was somewhat ineffective. Moore Jr. et al. [12] also reported significant reductions in ammonia volatilization from poultry manure amended with $\mathrm{Al}_{2} \mathrm{SO}_{4}$ and $\mathrm{FeSO}_{4}$. Although these chemical additives show promise for reducing environmental degradation from litter, the question of what effect these compounds have on manure decomposition rate has not been explored. This leads to the following question: what effect do these amendments have on agricultural production? Understanding how soil amendments containing $\mathrm{Al}, \mathrm{Fe}$, and $\mathrm{Ca}$ affect the $\mathrm{N}$ mineralization capacity of manure will aid in developing better management practices for manure application.

Periodic removal of litter from poultry houses is important to promote bird health and limit manure buildup [13]. Traditionally, poultry producers cleaned their houses to the ground (total cleanout) each year. While this management is still practiced by some, most producers no longer follow this procedure. Decaking (removal of the cake or top layer of harden manure) is becoming the most popular practice utilized by producers to save money and labor. This procedure involves removing the top portion of the litter, leaving behind the old bedding material. As a result, producers do not replace bedding materials as often. Thus, total cleanout of the litter is typically reduced to once every three to five years. Given that the cake contains a more concentrated manure component and less bedding than litter removed during total cleanout, the difference between the two poultry litter sources may influence $\mathrm{N}$ mineralization rates following land application for fertilization.

Continual changes in management practices can impact the sustainability of agricultural production. In order to keep producers abreast of the benefits and drawbacks from these changing practices, research must be done to evaluate their impact on agricultural productivity. A better understanding of how some recent manure management practices affect the decomposition and the availability of $\mathrm{N}$ is required. Therefore, the objective of this study was to determine impacts of chemical amendments added to poultry litter components, on $\mathrm{C}$ and $\mathrm{N}$ mineralization in a laboratory incubation study.

\section{Material and Methods}

2.1. Site Description for Incubated Soil. Soil for this study was collected from a bermudagrass (Cynodon dactylon) pasture located at the Sand Mountain Agriculture Research and Extension Center in the Appalachian Plateau region of northeast Alabama, USA. Soil was from plots that had not received manure within the last 10 years. The soil was a Hartsells fine sandy loam (fine-loamy, siliceous, subactive, thermic Typic Hapludults). The regional climate is subtropical with no dry season; mean annual rainfall is $1325 \mathrm{~mm}$, and mean annual temperature is $16^{\circ} \mathrm{C}$ [14]. Bulk soil samples were collected from the $0-20 \mathrm{~cm}$ depth and sieved through a $2 \mathrm{~mm}$ mesh screen to remove rocks and roots. Samples were stored in a cold room at $4^{\circ} \mathrm{C}$ until laboratory incubations were performed.

2.2. Experimental Treatments. A 35-day incubation study was conducted to measure $\mathrm{C}$ and $\mathrm{N}$ mineralization of soil amended with poultry litter containing different chemical amendments that had been previously reported to reduce $\mathrm{P}$ loss. Poultry litter components consisted of broiler cake, total cleanout, and bedding. Theses component were collected from a local broiler production facility in the Sand Mountain Region of north Alabama, USA. Broiler cake was collected following the decaking process during broiler house cleaning. Total cleanout litter was collected following the cleaning of a broiler house to the ground. Bedding material consisted of pine wood shavings. In order to apply small-uniform quantities of poultry litter for incubation, samples were air dried at $40^{\circ} \mathrm{C}$ and ground to pass through a $2 \mathrm{~mm}$ sieve. Characteristics of the poultry litter components are presented in Table 1. Laboratory grade chemicals consisting of gypsum $\left(\mathrm{CaSO}_{4}\right)$, lime $\left(\mathrm{CaCO}_{3}\right)$, ferrous sulfate $\left(\mathrm{FeSO}_{4}\right)$, and aluminum sulfate $\left(\mathrm{AlSO}_{4}\right)$ were used as the chemical amendments for this study.

2.3. Laboratory Analysis. Chemical analysis of soil and poultry litter component sources was performed by the Auburn University Soil Testing Laboratory as described by Hue and Evans [15]. Specifically, soil pH was determined on $1: 1$ soil/water suspensions with a glass electrode $\mathrm{pH}$ meter. Total $\mathrm{C}$ and $\mathrm{N}$ for the soil and poultry litter components were determined by dry combustion using a LECO TruSpec CN analyzer (LECO Corp., St. Joseph, MI). Concentrations of P, $\mathrm{K}, \mathrm{Ca}, \mathrm{Mg}$, and so forth were determined using a Mehlich 1 (double acid) extracting solution for soil [16] and with the dry ash procedure for poultry litter components [17]; both were measured by inductively coupled Argon plasma emission spectrometry [18] using an ICAP 9000 (Thermo Jarrell Ash, Franklin, MA). Soil textural analysis (percentage sand, silt, and clay) for the incubated soil was determined using the hydrometer method [19].

2.4. Incubation Study. Methods described by Torbert et al. [20] were utilized for quadruple determinations of potential $\mathrm{C}$ and $\mathrm{N}$ mineralization. Twenty-five grams of soil (ovendried weight basis), passed through a $2 \mathrm{~mm}$ sieve, were 
TABLE 1: Nutrient properties of soil and poultry litter components bedding, total cleanout, and broiler cake used for incubations, dry weight basis.

\begin{tabular}{|c|c|c|c|c|c|c|c|c|c|c|c|c|c|c|}
\hline Variables & $\mathrm{pH}$ & CEC & $\mathrm{C}$ & $\mathrm{N}$ & $\begin{array}{c}\mathrm{P} \\
\mathrm{P}_{2} \mathrm{O}_{5}\end{array}$ & $\begin{array}{c}\mathrm{K} \\
\mathrm{K}_{2} \mathrm{O}\end{array}$ & $\mathrm{Ca}$ & $\mathrm{Mg}$ & $\mathrm{Al}$ & B & $\mathrm{Cu}$ & $\mathrm{Fe}$ & $\mathrm{Mn}$ & $\mathrm{Zn}$ \\
\hline & & & & & $\mathrm{g} \mathrm{kg}^{-1}$ & & & & \multicolumn{6}{|c|}{$\mathrm{mg} \mathrm{kg}^{-1}$} \\
\hline \multicolumn{15}{|l|}{$\begin{array}{l}\text { Poultry litter } \\
\text { components }\end{array}$} \\
\hline Broiler cake & 7.6 & - & 375 & 42.1 & 41.3 & 37.4 & 25.0 & 60.0 & 997 & 39.0 & 461 & 903 & 751 & 572 \\
\hline Total cleanout & 8.5 & - & 262 & 31.3 & 48.4 & 32.3 & 37.5 & 64.0 & 2813 & 39.0 & 332 & 2115 & 509 & 439 \\
\hline Bedding & 4.9 & - & 456 & 0.50 & 1.0 & 1.4 & 1.3 & 0.20 & 203 & $<0.1$ & 13.36 & 4116 & 62 & 15 \\
\hline \multicolumn{15}{|l|}{$\underline{\text { Soil }}$} \\
\hline Sandy loam & 6.1 & 4.9 & 7.81 & 0.83 & 0.003 & 0.08 & 0.49 & 0.05 & 103 & $<0.1$ & 1 & 9 & 11 & 1 \\
\hline
\end{tabular}

placed in $118 \mathrm{~mL}(4-\mathrm{oz})$ plastic containers. The poultry litter component source (broiler cake, total cleanout, or bedding material) was added to soils at a rate of $350 \mathrm{~kg}$ total $\mathrm{N} \mathrm{ha}^{-1}$ (based on application to a $15 \mathrm{~cm}$ soil furrow slice) and mixed homogeneously to ensure uniformity within and between samples. Following poultry litter component addition, chemical amendments $\left(\mathrm{CaSO}_{4}, \mathrm{CaCO}_{3}, \mathrm{FeSO}_{4}\right.$, and $\mathrm{AlSO}_{4}$ ) were added to the soil at a rate that provided either $\mathrm{Al}, \mathrm{Fe}$, or $\mathrm{Ca}$ at an amount equivalent to the molar $\mathrm{P}$ content of the poultry litter component source (i.e., $651 \mathrm{~kg} \mathrm{ha}^{-1}$ gypsum, $480 \mathrm{~kg} \mathrm{ha}^{-1}$ lime, $930 \mathrm{~kg} \mathrm{ha}^{-1}$ ferrous sulfate, and $700 \mathrm{~kg} \mathrm{ha}^{-1}$ aluminum sulfate) with the greatest concentration. To facilitate uniform addition, chemical amendments were dissolved with deionized water and added to samples using a micropipette. Deionized water was added to bring the soil matric potential to approximately $-20 \mathrm{kPa}$ at a bulk density of $1.2 \mathrm{Mg} \mathrm{m}^{-3}$. After sample preparation, the containers were placed in $1.06 \mathrm{~L}$ widemouth incubation jars, and $10 \mathrm{~mL}$ of water was added to the bottom of each jar (not sample) for humidity control. Jars were incubated in the dark at $25^{\circ} \mathrm{C}$ and removed after 15 and 35 days for analysis of $\mathrm{C}$ and $\mathrm{N}$ mineralization.

Soil $\mathrm{C}$ mineralization was determined using a $10 \mathrm{~mL} \mathrm{CO}_{2}$ trap (vial containing $10 \mathrm{~mL} 1 \mathrm{~N} \mathrm{NaOH}$ ). The $\mathrm{CO}_{2}$ trap was placed in each jar and hermetically sealed. After removal, $1 \mathrm{~mL}$ of a saturated $\mathrm{BaCl}_{2}$ solution $(\sim 1 \mathrm{~N})$ was added to each sample to stop $\mathrm{CO}_{2}$ adsorption, and the $\mathrm{NaOH}$ was then backtitrated with $1 \mathrm{~N} \mathrm{HCl}$ using phenolphthalein as an indicator to determine the amount of $\mathrm{CO}_{2}$ released from soil samples. Soil $\mathrm{C}$ mineralization was determined as the difference between $\mathrm{CO}_{2}-\mathrm{C}$ captured in sample traps and from blanks (sealed jar without soil). The concentrations of $\mathrm{CO}_{2}$ determined on day 15 and 35 days after incubation were added together to determine the total amount of $\mathrm{C}$ mineralized for the $35 \mathrm{~d}$ incubation period, as described by Anderson (1982).

Soil $\mathrm{N}$ mineralization was determined by evaluating inorganic $\mathrm{N}$ concentrations during incubation. Concentrations of ammonium (NH4) and nitrite $(\mathrm{NO} 2)+$ nitrate $\left(\mathrm{NO}_{3}\right)$ were determined by extraction using $2 \mathrm{M} \mathrm{KCl}$ as described by Keeney and Nelson [21] and measured colorimetrically using

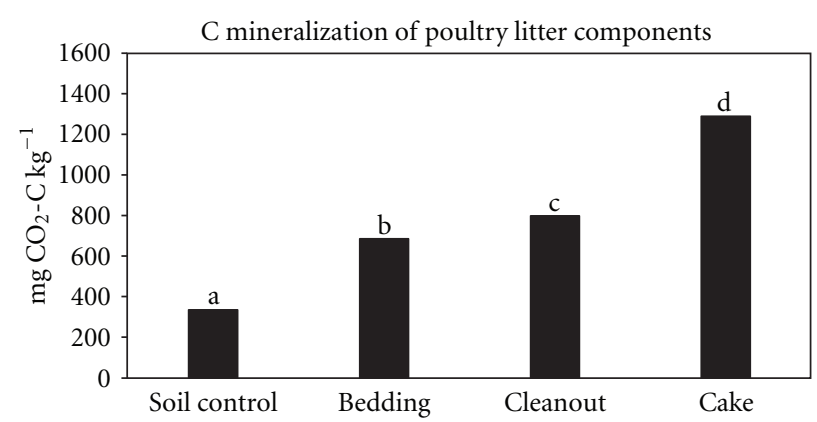

Figure 1: Effect of poultry litter components bedding, total cleanout, and broiler cake compared to a soil control on $\mathrm{C}$ mineralization following a 35-day incubation.

automated laboratory equipment (Bran-Luebbe, Norderstedt, Germany). Soil N mineralization was determined as the difference between final and initial inorganic $\mathrm{N}$ contents of the incubated sample.

2.5. Statistics. The incubation study was analyzed as a completely randomized design with four replications. There were 3 poultry litter sources X 5 chemical amendments $\mathrm{X} 4$ replications compared to a control (4 replicates) for a total of 64 experimental units. Statistical analyses were performed using the GLM procedure of SAS [22], and means were separated using least significant difference (LSD). A significance level of $\alpha<0.05$ was established $a$ priori.

\section{Results and Discussion}

Poultry litter is generally applied as a readily available $\mathrm{N}$ source to pastures in the southeastern USA. Thus, a common upland, well-drained, low microbial activity soil managed under bermudagrass pasture from the southeastern USA region was used to evaluate $\mathrm{C}$ and $\mathrm{N}$ mineralization for this study. The soil used for this incubation historically received minimal fertilization, no grazing, or harvesting for hay. Background nutrient concentrations for the soil 


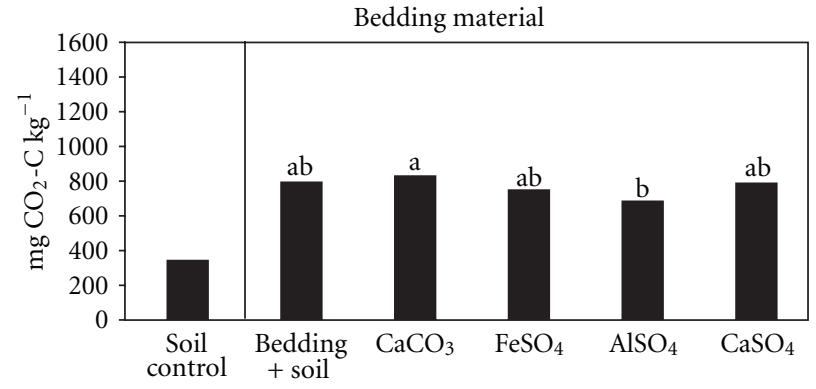

(a)

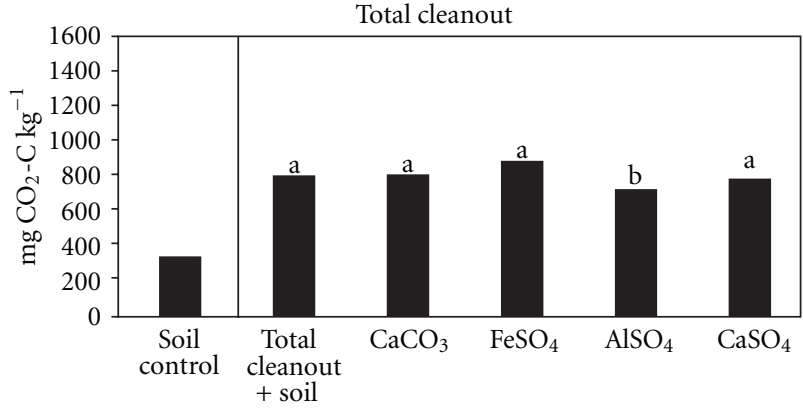

(b)

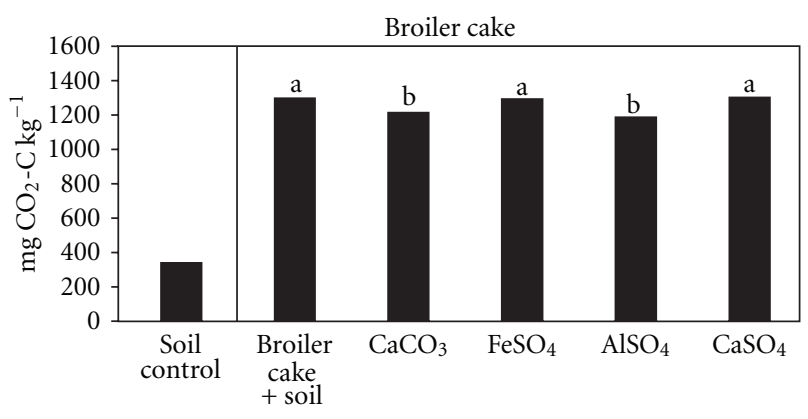

(c)

FIgUre 2: Effect of chemical amendments $\mathrm{CaCO}_{3}, \mathrm{FeSO}_{4}, \mathrm{AlSO}_{4}$, and $\mathrm{CaSO}_{4}$ on $\mathrm{C}$ mineralization of soil amended with poultry litter components bedding, total cleanout, and broiler cake following a 35-day incubation. Soil control is presented for comparison purposes of background levels.

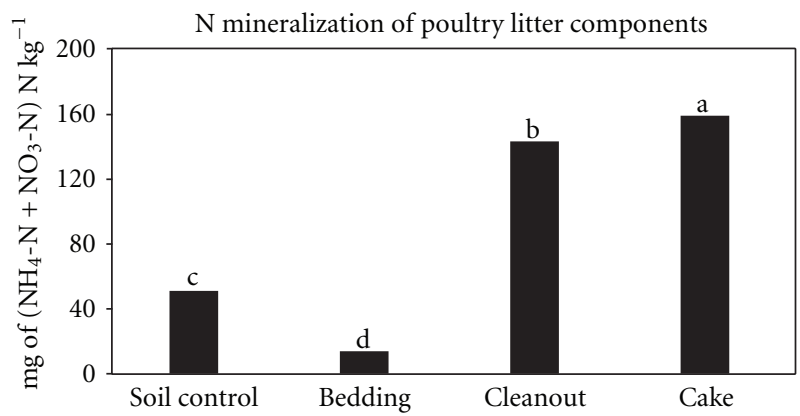

FIGURE 3: Effect of poultry litter components bedding, total cleanout, and broiler cake compared to a soil control on $\mathrm{N}$ mineralization following a 35-day incubation.

and poultry litter component sources used in this study are presented in Table 1. Nutrient concentrations varied among the poultry litter component sources. The bedding material had the greatest $\mathrm{C}$ concentrations compared to broiler cake and total cleanout. On the other hand, the bedding material $\mathrm{N}$ concentration was the lowest among the poultry litter component sources. Between the poultry litter component sources containing manure (broiler cake and total cleanout), broiler cake had greater $\mathrm{C}$ and $\mathrm{N}$ concentrations compared to the total cleanout, but $\mathrm{C}: \mathrm{N}$ ratios were similar between the two sources. Total $\mathrm{C}, \mathrm{N}$, and $\mathrm{C}: \mathrm{N}$ ratios were within the range reported by others in previous research $[13,23]$. The focus of this incubation study was to evaluate $\mathrm{C}$ and $\mathrm{N}$ cycling in soil following poultry litter addition amended with chemical amendments. Information from this study will aid in a better understanding of the $\mathrm{N}$-supplying potential of broiler cake and total cleanout amended with chemical additives containing $\mathrm{Al}, \mathrm{Fe}$, and Ca. For discussion purposes of this manuscript, $\mathrm{C}$ and $\mathrm{N}$ mineralization comparisons were made between the poultry litter components alone (without chemical amendments) and between chemical amendments for each poultry litter component source (broiler cake, total cleanout, and bedding) separately.

3.1. Soil Carbon Mineralization. Carbon mineralization is the conversion of organic $\mathrm{C}$ material into inorganic forms through soil microbial oxidation. This process occurs during decomposition. An evaluation of $\mathrm{C}$ mineralization can be used as an index to understand the decomposition rate of organic substances. Carbon evolution values observed on 15 $\mathrm{d}$ and $35 \mathrm{~d}$ were summed together and expressed as total C mineralized. Significant differences were observed in C mineralization rates resulting from the different poultry litter components (Figure 1). Cumulative soil C mineralization for the 35-day incubation period was $335 \mathrm{mg} \mathrm{kg}^{-1}$ for soil, $687 \mathrm{mg} \mathrm{kg}^{-1}$ for bedding, $801 \mathrm{mg} \mathrm{kg}^{-1}$ for total cleanout, and $1293 \mathrm{mg} \mathrm{kg}^{-1}$ for broiler cake. As expected, amending soil with the poultry litter components sources significantly increased $\mathrm{C}$ evolution, with broiler cake having the greatest $\mathrm{C}$ mineralization capacity compared to the other treatments. Carbon mineralization rates following the 35-day incubation 
was in the order of broiler cake $>$ total cleanout $>$ bedding $>$ soil control. Although bedding contained the most $\mathrm{C}$, the percentage of total $\mathrm{C}$ mineralized was less than the other poultry litter component sources. This suggests that the bedding is a more stable material than the litter sources containing manure (broiler cake and total cleanout). Also, the difference in $\mathrm{C}$ mineralization between the bedding and the other poultry litter component sources was most likely due to the amount of available N. Although the litter sources containing manure had a similar $\mathrm{C}: \mathrm{N}$ ratio, broiler cake had the highest $\mathrm{C}$ mineralization. Thus, since $\mathrm{N}$ was not a limiting factor, the poultry litter component source with the greatest $\mathrm{C}$ concentration mineralized the most when both broiler cake and total cleanout were applied at $350 \mathrm{~kg} \mathrm{~N} \mathrm{ha}{ }^{-1}$. Also, it is important to note that the total cleanout contained a greater percentage of bedding material compared to the broiler cake. Thus, the total cleanout most likely contained more stable $\mathrm{C}$ compared to the cake. Since broiler cake consisted of a lower recalcitrant form of organic $\mathrm{C}$, it contributed to a greater mineralization capacity. Although $\mathrm{C}$ mineralization data reported for this study represent the total $\mathrm{C}$ mineralized during the two sampling periods (15 and 35 days after incubation), it is important to note that a significantly greater $\mathrm{C}$ mineralization rate was observed during the second portion of the incubation for the bedding material (data not shown). The other poultry litter components generally resulted in a slightly lower C mineralization rate.

Addition of chemical amendments to the incubated soil also impacted carbon mineralization. Differences in C mineralization rates for each chemical compound added to the broiler cake, total cleanout, and bedding amended soil are illustrated in Figure 2. Chemical amendment additions impacted $\mathrm{C}$ mineralization differently depending on the poultry litter component (total cleanout, broiler cake, and bedding) evaluated. For instance, significant differences were observed among chemical amendments in the bedding treatment (i.e., $\mathrm{CaCO}_{3}>\mathrm{AlSO}_{4}$ ) with $\mathrm{CaCO}_{3}$ producing the greatest $\mathrm{C}$ mineralization; however when each chemical amendment was compared to the no chemical amendment bedding treatment (bedding + soil only), no significant differences were observed. Cumulative $\mathrm{C}$ mineralization in the total cleanout treatment was significantly increased with $\mathrm{FeSO}_{4}$, producing significantly greater $\mathrm{C}$ mineralization rates compared to the other treatments. No significant differences were observed between the $\mathrm{CaSO}_{4}, \mathrm{FeSO}_{4}, \mathrm{AlSO}_{4}$, and the no chemical amendment treatment (total cleanout + soil only). In the broiler cake treatment, no significant differences were observed between $\mathrm{CaSO}_{4}, \mathrm{FeSO}_{4}$, and the no chemical amendment broiler cake treatment (broiler + soil only), while $\mathrm{CaCO}_{3}$ and $\mathrm{AlSO}_{4}$ produced statistically lower C mineralization.

3.2. Soil Nitrogen Mineralization. Nitrogen in manure is primarily in an organic form. Before plant uptake can occur, it must be converted to inorganic forms of $\mathrm{N}$. This is achieved via microbes as a by-product of organic matter decomposition in a process called $\mathrm{N}$ mineralization. Understanding of how recent changes in poultry litter management practices affect $\mathrm{N}$ mineralization can help improve $\mathrm{N}$ management for crop demands.

Similar to $\mathrm{C}$ mineralization, addition of the different poultry litter components impacted $\mathrm{N}$ mineralization. Mean $\mathrm{N}$ mineralization observed during the 35-day incubation is presented in Figure 3. Cumulative soil $\mathrm{N}$ mineralizations for the 35 -day incubation period were $51 \mathrm{mg} \mathrm{kg}^{-1}$ for soil, $13 \mathrm{mg}$ $\mathrm{kg}^{-1}$ for bedding material, $143 \mathrm{mg} \mathrm{kg}^{-1}$ for total cleanout, and $159 \mathrm{mg} \mathrm{kg}^{-1}$ for broiler cake. Addition of bedding resulted in a lower mineralization compared to the soil control (no chemical amendment or poultry litter addition), while broiler cake and total cleanout amended soils resulted in greater $\mathrm{N}$ availability. This was to be expected since wood shavings (bedding) are highly stable carbonaceous material with a $C: N$ ratio of $143: 1$. As rule of thumb, a $C: N$ ratio of $20: 1$ is the breakeven point between immobilization and $\mathrm{N}$ release. When organic materials with $\mathrm{C}: \mathrm{N}$ ratios greater than $30: 1$ are added to soil, there is $\mathrm{N}$ immobilization during the initial decomposition process. Thus, the highly carbonaceous bedding material supplied the microbes with a new energy source, but insufficient $\mathrm{N}$ to build protein. Thus the soil microbes scavenged $\mathrm{N}$ from the soil, thereby reducing $\mathrm{N}$ availability, or, in other words, caused net $\mathrm{N}$ immobilization. Broiler cake produced the highest $\mathrm{N}$ mineralization capacity compared to the other poultry litter components evaluated during this incubation study. Although the broiler cake and total cleanout had similar $\mathrm{C}: \mathrm{N}$ ratios (8.9 broiler cake and 8.4 total cleanout), broiler cake most likely contains a more energy-rich supply of $\mathrm{C}$ compared to the total cleanout. For instance, the carbon source (although not quantified) in the cake portion of the litter in broiler houses generally contains a higher concentration of manure while the total cleanout contains both manure and bedding.

Use of chemical amendments with the different poultry litter components resulted in $\mathrm{N}$ availability differences following the 35-day incubation (Figure 5). Generally, all of the chemical amendments negatively impacted $\mathrm{N}$ availability when compared with poultry litter component sources. There was a significant interaction between the poultry litter components and the chemical amendments. For the bedding material, adding chemical amendments produced a statistically similar $\mathrm{N}$ rate compared to the no chemical amendment bedding treatment (bedding + soil only). The $\mathrm{CaCO}_{3}$ amendment produced the greatest $\mathrm{N}$ mineralization rate compared to the other chemical amendments applied to the bedding material. Nitrogen mineralization for $\mathrm{CaCO}_{3}$, $\mathrm{FeSO}_{4}$, and $\mathrm{CaSO}_{4}$ was statistically similar to the no chemical amendment bedding treatment, while the $\mathrm{AlSO}_{4}$ produced a statistically lower $\mathrm{N}$ mineralization rate. Addition of $\mathrm{AlSO}_{4}$ to the bedding material, which was slightly acidic, could have caused Al toxicity to the soil microbes that were responsible for decomposition. Chander and Brookes [24] reported that $\mathrm{Al}$ concentrations at low $\mathrm{pH}$ can directly affect microbial biomass and indirectly decrease inputs of soil plant-derived substrates.

Results of $\mathrm{N}$ mineralization for chemical amendment additions to total cleanout are reported in Figure 4. Addition of chemical amendments $\mathrm{FeSO}_{4}, \mathrm{AlSO}_{4}$, and $\mathrm{CaSO}_{4}$ to soil amended with total cleanout resulted in $\mathrm{N}$ mineralization 


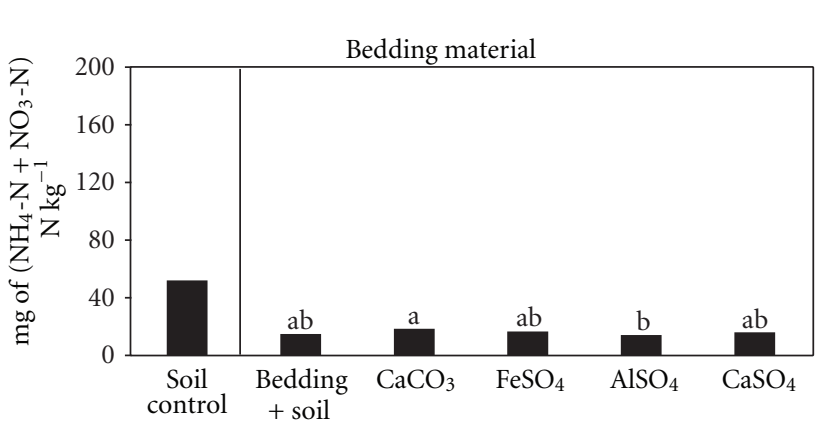

(a)

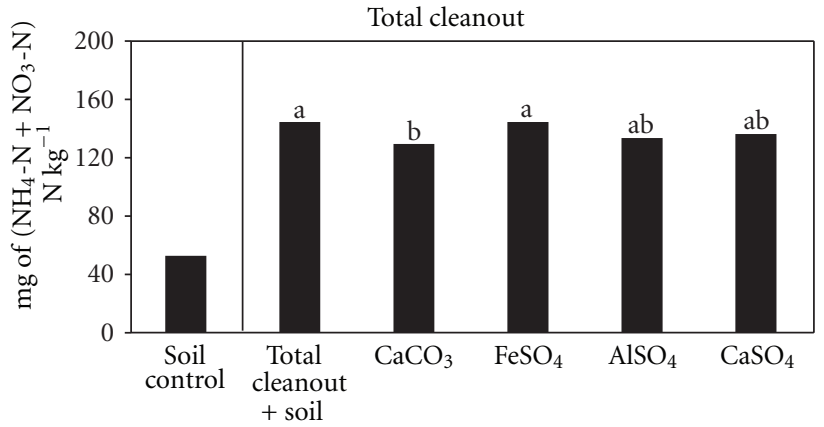

(b)

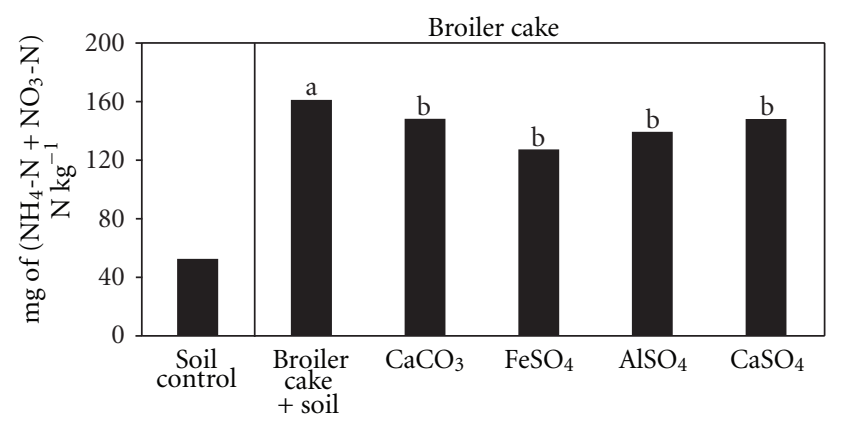

(c)

Figure 4: Effect of chemical amendments $\mathrm{CaCO}_{3}, \mathrm{FeSO}_{4}, \mathrm{AlSO}_{4}$, and $\mathrm{CaSO}_{4}$ on $\mathrm{N}$ mineralization of soil amended with poultry litter components bedding, total cleanout, and broiler cake following a 35-day incubation. Soil control is presented for comparison purposes of background levels.

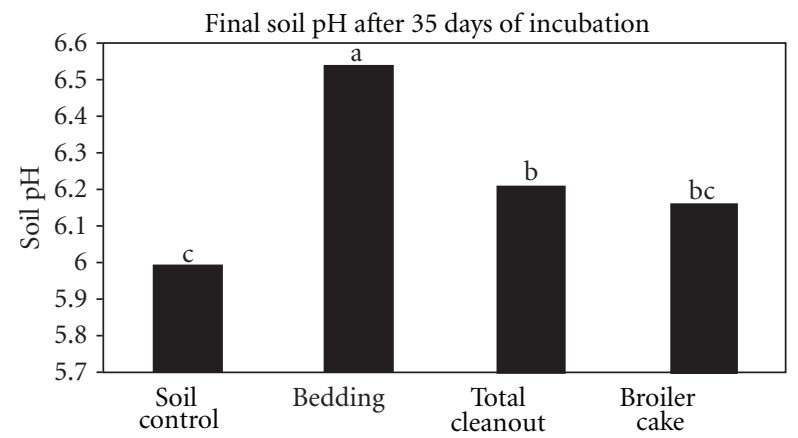

Figure 5: Effect of poultry litter components bedding, total cleanout, and broiler cake compared to a soil control on soil $\mathrm{pH}$.

statistically similar to the no chemical amendment total cleanout treatment. However, addition of $\mathrm{CaCO}_{3}$ to the total cleanout amended soil resulted in a statistically lower $\mathrm{N}$ mineralization rate compared to when no chemical amendments were applied. Originally, the $\mathrm{pH}$ of the total cleanout was 8.5 ; thus addition of the liming agent to an already basic material had a negative effect on the $\mathrm{N}$ mineralization.

When evaluating the effect of chemical additions to broiler cake amended soil, a slightly different effect was observed in the $\mathrm{N}$ mineralization. All of the chemical amendments evaluated resulted in statistically lower plant available $\mathrm{N}$ during the 35-day incubation compared to the no chemical amendment broiler cake treatment. Although all the chemical amendments decreased $\mathrm{N}$ mineralization, the rate of decrease among treatments with chemical amendments was statistically similar. These results suggest that chemical amendments added to land-applied poultry litter to decrease $\mathrm{P}$ loss with surface water runoff or in the poultry production facilities to reduce $\mathrm{NH}_{3}$ volatilization during growout could affect $\mathrm{N}$ availability to crops.

3.3. Soil $p H$ Change. Addition of the poultry litter component sources significantly impacted $\mathrm{pH}$ of the incubated soil. Soil $\mathrm{pH}$ during the 35 -day incubation containing the poultry litter component sources and soil control are shown in Figure 5. Initial soil $\mathrm{pH}$ prior to the incubation was 6.1. The soil control $\mathrm{pH}$ was essentially unchanged following the 35-day incubation (6.0). Poultry litter additions significantly increased soil $\mathrm{pH}$ compared to the soil control. The greatest $\mathrm{pH}$ change was observed in soil amended with bedding material followed by total cleanout, broiler cake, and soil control. Generally, poultry litter is not a liming material, but because of the alkaline $\mathrm{pH}$ and large $\mathrm{Ca}$ content, the broiler cake and total cleanout amendments increased the incubated soil's $\mathrm{pH}$. Increases in soil $\mathrm{pH}$ following poultry litter addition have been reported by others [25-27]. Moore and Edwards [27] reported an increase in $\mathrm{pH}$ from 5.1 to 5.8 after poultry litter was applied for 7 years. On the other hand, an unexpected increase was also observed with the bedding material, but this phenomenon cannot be explained from previous reports. 


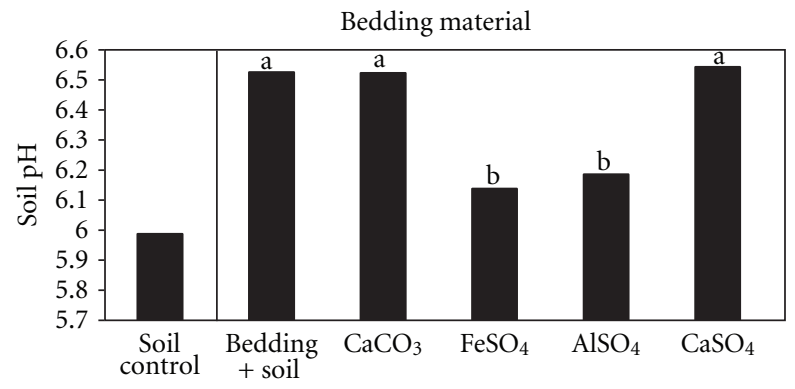

(a)

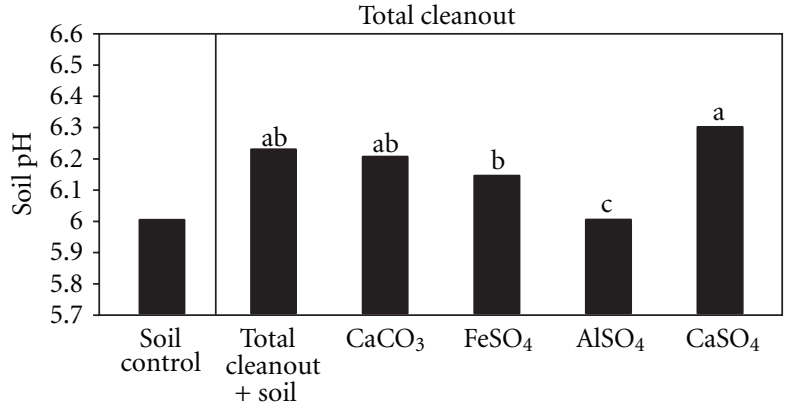

(b)

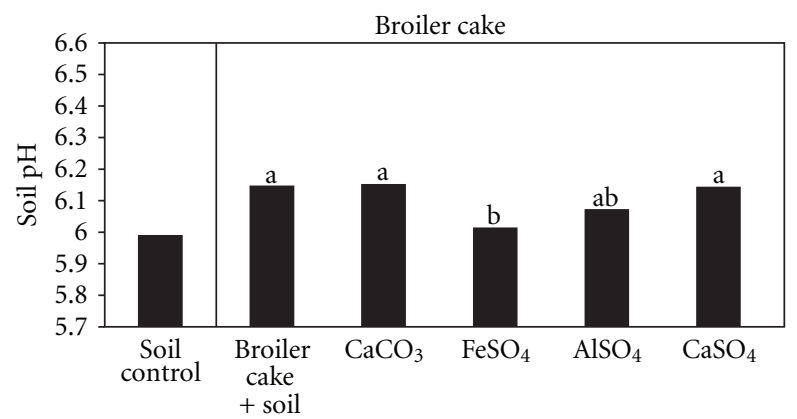

(c)

Figure 6: Effect of chemical amendments $\mathrm{CaCO}_{3}, \mathrm{FeSO}_{4}, \mathrm{AlSO}_{4}$, and $\mathrm{CaSO}_{4}$ on the $\mathrm{pH}$ of soil amended with poultry litter components bedding, total cleanout, and broiler cake following a 35-day incubation. Soil control is presented for comparison purposes of background levels.

Chemical amendment addition to soil with the poultry litter components also impacted $\mathrm{pH}$ levels (Figure 6). The general $\mathrm{pH}$ trend resulting from chemical amendment additions to the incubated soil containing the different poultry litter components was statistically similar between the no chemical amendment, $\mathrm{CaSO}_{4}$, and $\mathrm{CaCO}_{3}$ treatments; lower levels were observed for $\mathrm{AlSO}_{4}$ and $\mathrm{FeSO}_{4}$. Evaluation of the chemical amendment additions to the incubated soil with bedding was similar to the general trend with no significant difference being observed between the no chemical amendment, $\mathrm{CaSO}_{4}$, and $\mathrm{CaCO}_{3}$ treatments, while $\mathrm{AlSO}_{4}$ and $\mathrm{FeSO}_{4}$ resulted in significantly lower soil $\mathrm{pH}$. Significant differences were also observed for the total cleanout. No significant difference was observed between the no chemical amendment, $\mathrm{CaSO} 4, \mathrm{FeSO}_{4}$, and $\mathrm{CaCO}_{3}$ treatments. The addition of $\mathrm{AlSO}_{4}$ to the total cleanout treatment resulted in decreases to soil $\mathrm{pH}$. An evaluation of broiler cake showed that $\mathrm{AlSO}_{4}$ and $\mathrm{FeSO}_{4}$ resulted in the lowest $\mathrm{pH}$ values similar to the bedding and total cleanout poultry litter component. However, $\mathrm{AlSO}_{4}$ was the only chemical amendment that was statistically different from the no chemical amendment broiler cake treatment.

\section{Conclusions}

Nitrogen is the most limiting nutrient in a crop production system. When manure sources are used for $\mathrm{N}$ fertilization, $\mathrm{N}$ mineralization accounts for most of the crop $\mathrm{N}$ needs. An understanding of how manure management practices affect $\mathrm{N}$ availability is important to maintain crop yields. The information obtained from this incubation study may be useful when considering fertilization with poultry litter. For instance, should poultry litter cake or cleanout be used for $\mathrm{N}$ fertilization and which chemical amendment provides the best $\mathrm{N}$ availability? Carbon mineralization, which is a representation of microbial activity, was increased by the addition of the poultry litter components. Even though the bedding material had the greatest $C$ source, broiler cake had the highest $\mathrm{C}$ mineralization rate. Carbon mineralization was in the order of broiler cake, total cleanout, and bedding. Evaluation of $\mathrm{N}$ mineralization showed that the bedding material resulted in severe $\mathrm{N}$ immobilization. On the other hand, broiler cake had the highest $\mathrm{N}$ mineralization rate followed by total cleanout. Addition of chemical amendments to the poultry litter components also impacted $\mathrm{C}$ mineralization. The greatest differences in $\mathrm{C}$ mineralization were observed with $\mathrm{AlSO}_{4}$, generally decreasing mineralization. Chemical amendment additions also resulted in significant $\mathrm{N}$ mineralization differences. The greatest differences were observed in the broiler cake treatment. All chemical amendments applied to the broiler cake amended soil resulted in decreased $\mathrm{N}$ mineralization compared to the no chemical amendment treatment. For the total cleanout treatment, $\mathrm{CaCO}_{3}$ was the only chemical amendment to decrease $\mathrm{N}$ mineralization compared to the no chemical amendment treatment. These results suggest that while the use of chemical amendments has been shown to reduce $\mathrm{P}$ loss and decrease $\mathrm{NH}_{3}$ volatilization, a reduction in $\mathrm{N}$ mineralization may also occur. Also 
changes in poultry litter management practices are likely to impact $\mathrm{N}$ availability in soil.

\section{References}

[1] P. A. Moore Jr. and D. M. Miller, "Decreasing phosphorus solubility in poultry litter with aluminum, calcium, and iron amendments," Journal of Environmental Quality, vol. 23, no. 2, pp. 325-330, 1994.

[2] D. L. Anderson, O. H. Tuovinen, A. Faber, and I. Ostrokowski, "Use of soil amendments to reduce soluble phosphorus in dairy soils," Ecological Engineering, vol. 5, no. 2-3, pp. 229-246, 1995.

[3] T. H. Dao, "Coamendments to modify phosphorus extractability and nitrogen/phosphorus ratio in feedlot manure and composted manure," Journal of Environmental Quality, vol. 28, no. 4, pp. 1114-1121, 1999.

[4] Z. Dou, G. Y. Zhang, W. L. Stout, J. D. Toth, and J. D. Ferguson, "Efficacy of alum and coal combustion by-products in stabilizing manure phosphorus," Journal of Environmental Quality, vol. 32, no. 4, pp. 1490-1497, 2003.

[5] M. Kalbasi and K. G. Karthikeyan, "Phosphorus dynamics in soils receiving chemically treated dairy manure," Journal of Environmental Quality, vol. 33, no. 6, pp. 2296-2305, 2004.

[6] H. A. Torbert, K. W. King, and R. D. Harmel, "Impact of soil amendments on reducing phosphorus losses from runoff in sod," Journal of Environmental Quality, vol. 34, no. 4, pp. 1415-1421, 2005.

[7] D. B. Watts and H. A. Torbert, "Impact of gypsum applied to grass buffer strips on reducing soluble $\mathrm{p}$ in surface water runoff," Journal of Environmental Quality, vol. 38, no. 4, pp. 15111517, 2009.

[8] D. Brauer, G. E. Aiken, D. H. Pote et al., "Amendment effects on soil test phosphorus," Journal of Environmental Quality, vol. 34, no. 5, pp. 1682-1686, 2005.

[9] Y. Ann, K. R. Reddy, and J. J. Delfino, "Influence of chemical amendments on phosphorus immobilization in soils from a constructed wetland," Ecological Engineering, vol. 14, no. 1-2, pp. 157-167, 1999.

[10] F. N. Reece, B. J. Bates, and B. D. Lott, "Ammonia control in broiler houses," Poultry Science, vol. 58, pp. 754-755, 1979.

[11] M. Kithome, J. W. Paul, and A. A. Bomke, "Reducing nitrogen losses during simulated composting of poultry manure using adsorbents or chemical amendments," Journal of Environmental Quality, vol. 28, no. 1, pp. 194-201, 1999.

[12] P. A. Moore Jr., T. C. Daniel, D. R. Edwards, and D. M. Miller, "Effect of chemical amendments on ammonia volatilization from poultry litter," Journal of Environmental Quality, vol. 24, no. 2, pp. 293-300, 1995.

[13] K. R. Sistani, G. E. Brink, S. L. McGowen, D. E. Rowe, and J. L. Oldham, "Characterization of broiler cake and broiler litter, the by-products of two management practices," Bioresource Technology, vol. 90, no. 1, pp. 27-32, 2003.

[14] R. H. Shaw, "Climate of the United States," in Handbook of Soils and Climate in Agriculture, V. J. Kilmer, Ed., CRC Press, Boca Raton, Fla, USA, 1982.

[15] N. V. Hue and C. E. Evans, Procedures used for soil and plant analysis by the Auburn University Soil Testing Laboratory, Auburn University, Auburn, Ala, USA, 1986.

[16] S. R. Olsen and L. E. Sommers, "Phosphorus," in Methods of Soil Analysis Part 2, A. L. Page, Ed., Agronomy Monograph 9, pp. 403-430, ASA and SSSA, Madison, Wis, USA, 1982.
[17] S. J. Donahue, Reference soil test methods for the Southern Region of the United State, Southern Cooperative Service, Bulletin 289, Georgia Agricultural Experiment Station, Athens, Ga, USA, 1983.

[18] P. N. Soltanpour, J. B. Jones, and S. M. Workman, "Optical emission spectrometry," in Methods of Soil Analysis. Part 2, A. L. Page et al., Ed., Agronomy Monograph 9, pp. 29-65, ASA and SSSA, Madison, Wis, USA, 2nd edition, 1982.

[19] G. J. Bouyoucos, "Hydrometer method for making particle analysis of soil," Agronomy Journal, vol. 54, pp. 464-465, 1962.

[20] H. A. Torbert, S. A. Prior, and D. W. Reeves, "Land management effects on nitrogen and carbon cycling in an ultisol," Communications in Soil Science and Plant Analysis, vol. 30, no. 9-10, pp. 1345-1359, 1999.

[21] D. R. Keeney and D. W. Nelson, "Nitrogen: inorganic forms," in Methods of Soil Analysis. Part 1, A. L. Page et al., Ed., Agronomy Monograph 9, pp. 643-698, ASA and SSSA, Madison, Wis, USA, 2nd edition, 1982.

[22] SAS Institute, SAS, version 9.1, SAS Institute, Cary, NC, USA, 2002.

[23] P. L. Ward, J. E. Wohlt, P. K. Zajac, and K. R. Cooper, "Chemical and physical properties of processed newspaper compared to wheat straw and wood shavings as animal bedding," Journal of Dairy Science, vol. 83, no. 2, pp. 359-367, 2000.

[24] K. Chander and P. C. Brookes, "Synthesis of microbial biomass from added glucose in metal-contaminated and non-contaminated soils following repeated fumigation," Soil Biology and Biochemistry, vol. 24, no. 6, pp. 613-614, 1992.

[25] E. E. Codling, R. L. Chaney, and C. L. Mulchi, "Use of aluminum- and iron-rich residues to immobilize phosphorus in poultry litter and litter-amended soils," Journal of Environmental Quality, vol. 29, no. 6, pp. 1924-1931, 2000.

[26] G. Gupta and S. Charles, "Trace elements in soils fertilized with poultry litter," Poultry Science, vol. 78, no. 12, pp. 1695$1698,1999$.

[27] P. A. Moore and D. R. Edwards, "Long-term effects of poultry litter, alum-treated litter, and ammonium nitrate on aluminum availability in soils," Journal of Environmental Quality, vol. 34, no. 6, pp. 2104-2111, 2005. 


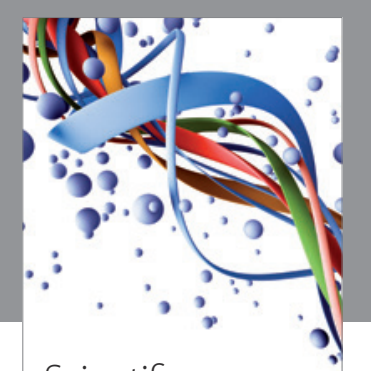

Scientifica
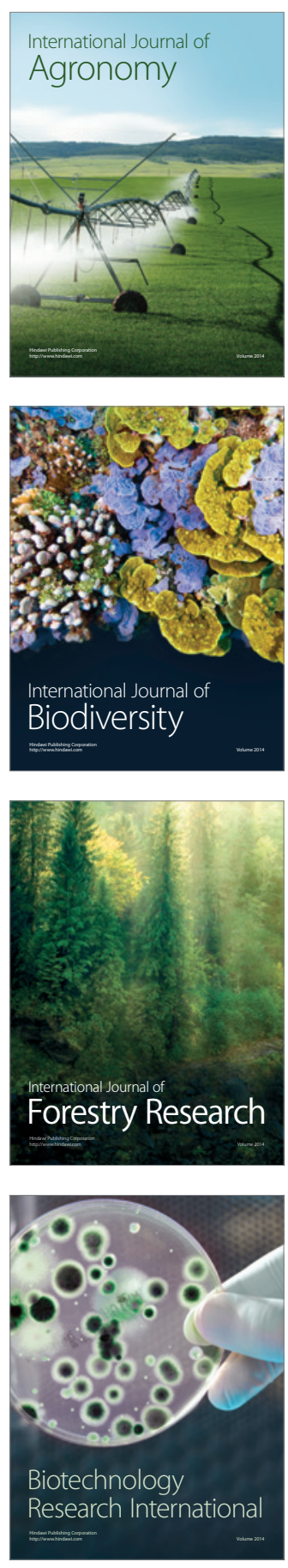
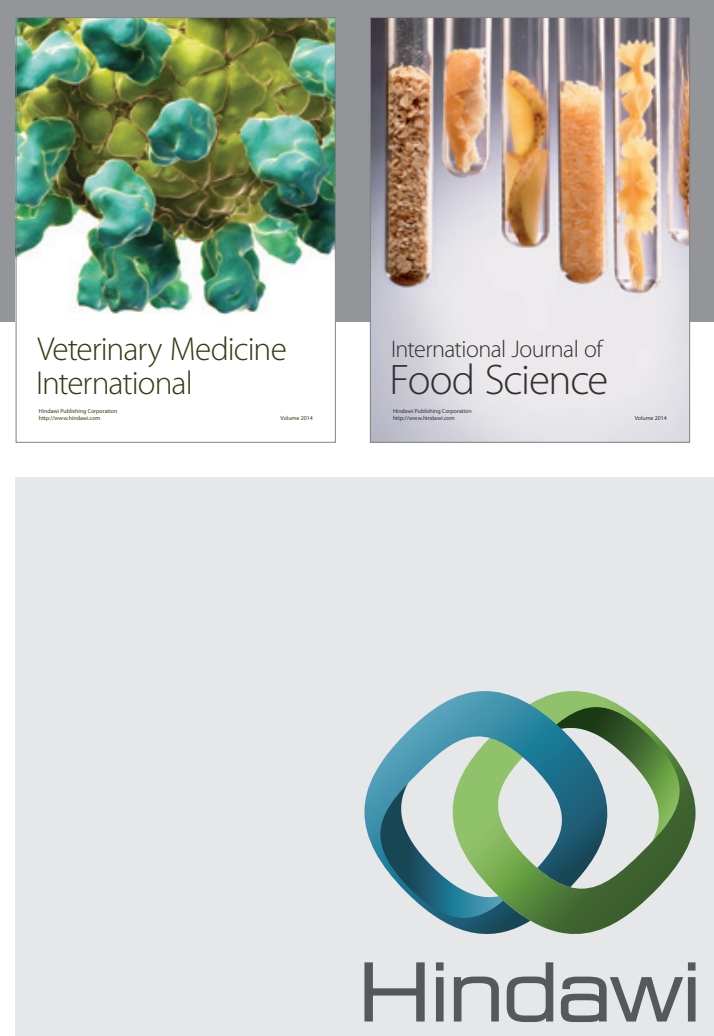

Submit your manuscripts at

http://www.hindawi.com
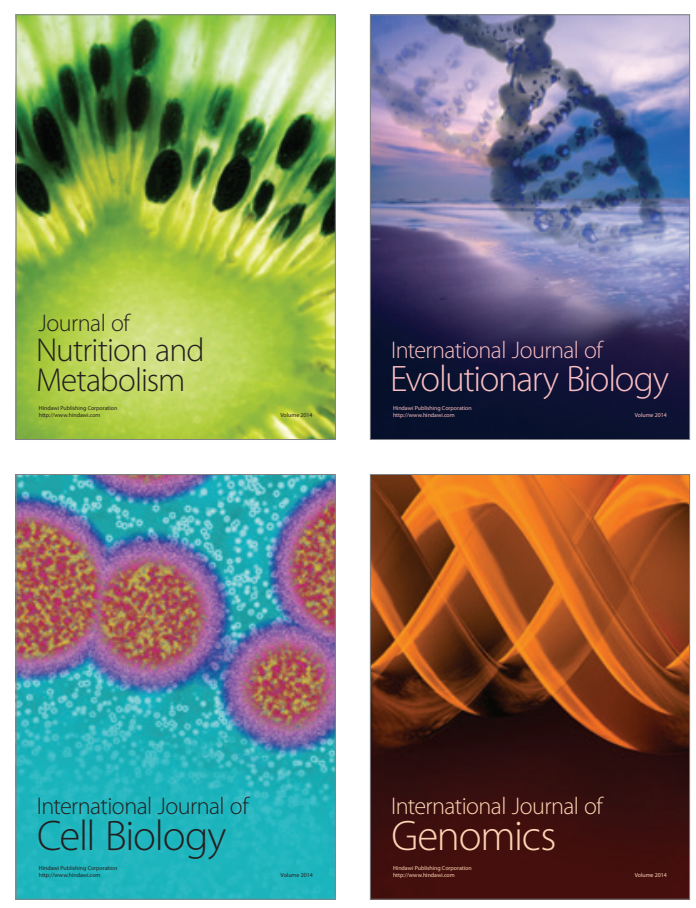
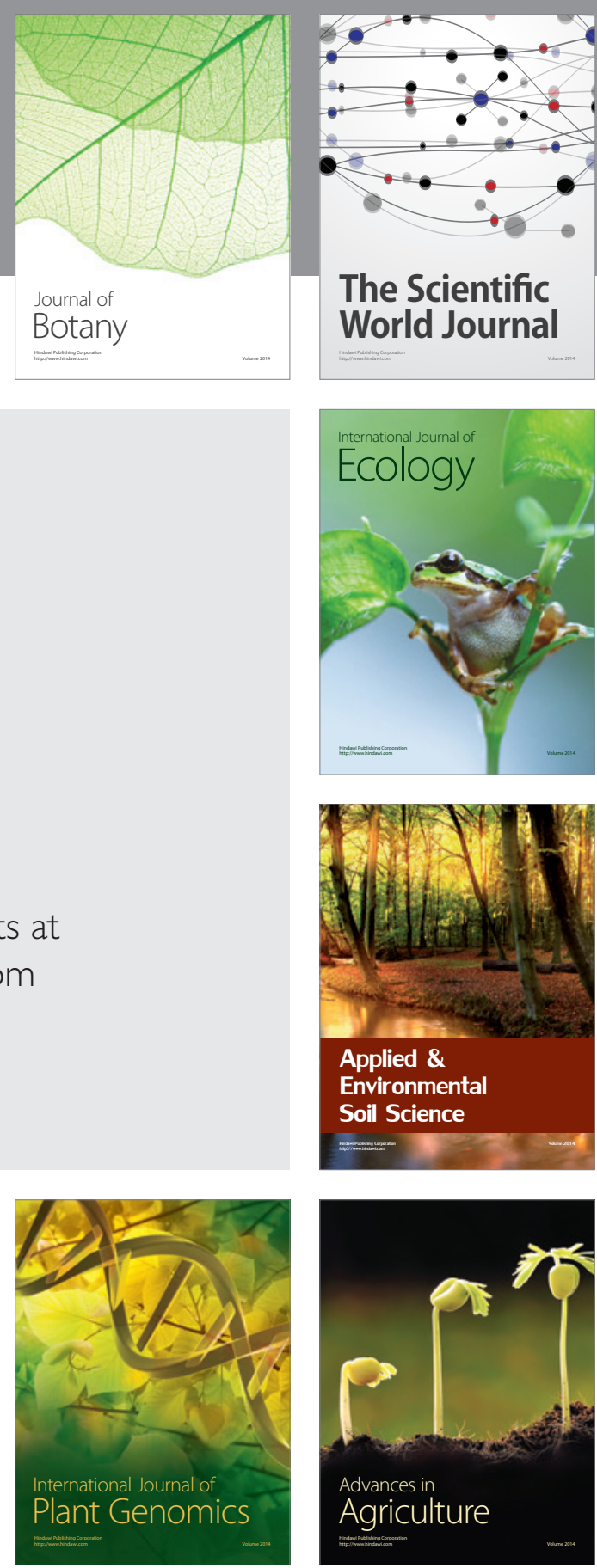

The Scientific World Journal
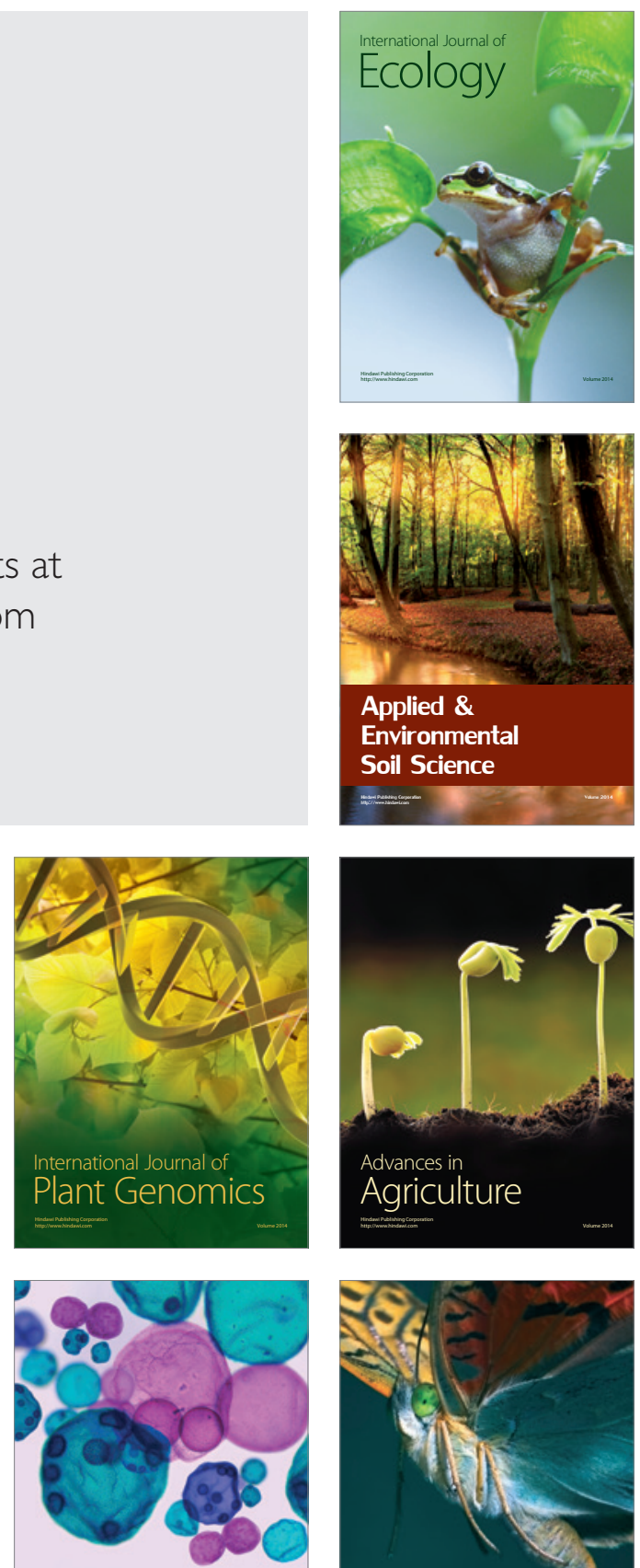

International Journal of Microbiology

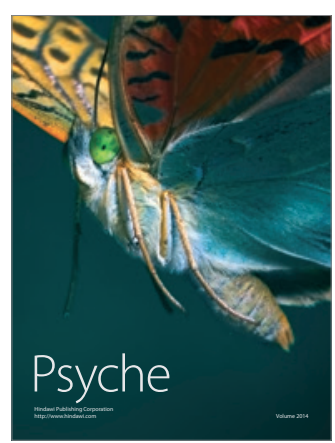

